\title{
弾性ロケット及びランチャーの発射時の三次元動的解析*1 Three Dimensional Analysis of Elastic Rocket and Launcher at Launching
}

\author{
竹内 伸 介 $^{* 2}$ \\ Shinsuke TAKEUCHI
}

Key Words : Launcher, Elastic Vibration, Trajectory Dispersion

\begin{abstract}
In this paper, a three-dimensional analysis of launching dynamics of a sounding rocket is investigated. In the analysis, the elastic vibration of the vehicle and launcher is considered. To estimate a trajectory dispersion including the effect of elasticity of the vehicle and launcher, a three-dimensional numerical simulation of a launch is performed. The accuracy of the numerical simulation is discussed and it is concluded that the simulation can estimate the maximum value of the trajectory dispersion properly. After that, the maximum value is estimated for the actual sounding rocket and the value is shown to be within the safty margin for this particular case.
\end{abstract}

記

号

$A:$ ランチャーレールの単位長さあたりの捻れ角 $b$ :ロケット中心軸から上段翼端までの距離

$C_{N \alpha}:$ ロケットの単位長さあたりの法線力係数傾斜

$\vec{C}_{j i}: \vec{C}_{j i}=\left[\left[\mu_{R}\left(\vec{\eta}_{R i} \times \vec{\eta}_{R j}\right)\right]\right]_{R} / m$, 式 (28) 参照

$D_{i X}, D_{i Y}, D_{i Z}, D_{i \Phi}: i$ 番目接触部でのロケットとランチ ヤーの $X, Y, Z$ 方向及び $X$ 軸周り相対変位 $D_{i X}^{*}, D_{i Y}^{*}, D_{i Z}^{*}, D_{i \Phi}^{*}: i$ 番目接触部でのランチャーの $X$, $Y, Z$ 方向及び $X$ 軸周り弾性変形量

$d_{i X}, d_{i Y}, d_{i z}, d_{i x}, d_{i y}, d_{i z}: i$ 番目接触部でのロケットの

$X, Y, Z, x, y, z$ 方向弾性変形量

$E:(X, Y, Z)$ から $(x, y, z) \sim 0$ 座標変換行列

$g:$ 重力加速度

$I_{i j}: i, j=x, y, z$, ロケットの慣性乗積

$J: ロ ケ ッ ト の$ 曲げ剛性

$K_{i}, K_{i}^{*}: i$ 番目接触部に導入するバネ定数

$m, m_{L}$ : ロケット及びランチャーの質量

$N_{R}, N_{L}$ : ロケット及びランチャーの低次元化モデルの 次数

$p, q, r$ ：ロケット重心周り剛体回転角速度の $x, y, z$ 軸周り成分

$R_{i X}, R_{i Y}, R_{i Z}, R_{i \Phi}, R_{i \Theta}, R_{i \Psi}: i$ 番目接触部でロケットがラ ンチャーに及济す $X, Y, Z$ 方向の力と各軸 周りのモーメント, 第 3 図参照

$r_{i x}, r_{i y}, r_{i z}, r_{i \phi}, r_{i \theta}, r_{i \psi}: i$ 番目接触部でランチャーがロ ケットに及ぼす $x, y, z$ 方向の力と各軸周り のモーメント

\footnotetext{
*1 (C) 2001 日本航空宇宙学会
}

平成 12 年 11 月 27 日原稿受理

*2 東京大学大学院工.学系研究科航空宇宙工学専攻
$S_{D}$ : 法線力係数傾斜に対する基準断面積

$T:$ ロケットの推力

$v, v_{x}, v_{y}, v_{z}$ : ロケット重心速さとその $x, y, z$ 成分

$\vec{w}:(x, y, z)$ 座標系で見たロケットの弾性変形

$X, Y, Z:$ 静止座標系

$x, y, z$ : ロケットに固定された座標系

$X_{C G}, Y_{C G}, Z_{C G}$ : ロケット重心位置の $X, Y, Z$ 成分

$X_{C G 0}, Y_{C G 0}, Z_{C G 0}$ : ロケット重心位置の初期值

$X_{R C G i}: i$ 番目接触部でロケットがランチャーと接触 しなくなるときの重心の $X$ 座標

$x_{1}, x_{2}, x_{T}$ : 力 $\boldsymbol{R}_{1}, \boldsymbol{R}_{2}, T$ 作用点の $x$ 座標, 第 3 図参照

$\alpha_{y}, \alpha_{z}: x y, x z$ 平面内の機体中心軸接線方向に対す る気流の流入角

$\Delta \psi, \Delta \theta$ : 方位角, 迎角方向軌道分散量

$\zeta_{R i}, \zeta_{L i}$ : ロケット及びランチャーの $i$ 次モード減衰比 $\eta_{R i x}, \eta_{R i y}, \eta_{R i z}, \eta_{R i \phi}, \eta_{R i \theta}, \eta_{R i \psi}:$ ロ ットの $i$ 次モード形 状の $x, y, z$ 方向及び各軸周り成分

$\eta_{L i X}, \eta_{L i Y}, \eta_{L i Z}, \eta_{L i \Phi}, \eta_{L i \Theta}, \eta_{L i \Psi}:$ ランチャーの $i$ 次モード 形状の $X, Y, Z$ 方向及び各軸周り成分

$\xi_{R i}, \xi_{L i}:$ ロケット及びランチャーの $i$ 次モード変位

$\omega_{R i}, \omega_{L i}:$ ロケット及びランチャーの $i$ 次モード角振動 数

$\Theta_{L I}: X$ 軸と水平面のなす角度

$\Phi, \Theta, \Psi:(x, y, z)$ 座標系の向きを表すオイラー角

$\rho_{a}:$ 空気密度

$\mu_{i}: i$ 番目接触部の摩擦係数

$\mu_{R}, \mu_{L}$ : ロケット及びランチャーを構成する梁の線密 度

$[[\cdots]]_{R},[[\cdots]]_{L}$ : ロケット及びランチャーを構成する梁 の中心軸に沿った積分 


\section{1.は じめに}

多くの観測ロケット及び宇宙科学研究所の $\mathrm{M}-\mathrm{V}$ 型に代 表される一部の衛星打ち上げロケットでは，ロケットが一 定の速度を得るまで支持するランチャーと呼ばれる発射台 が使用されている。発射にランチャーを用いる場合，口ケ ットとランチャーの相互干涉によって生じる弾性振動によ る荷重や軌道分散について考慮する必要がある．多くの場 合ランチャーはある鉛直面に対して対称であり，ロケット は同じ鉛直面に対して対称な直線のレールを用いて発射さ れる。この場合ランチャーの中心線とロケットの重心が同 一の鉛直面内となるため，理想的な状況では鉛直面外方向 の力は作用せず，発射時の運動もその鉛直面内の運動が支 配的となる。そこで従来の研究では，「発射時のロケット 及びランチャーの運動は発射方向を含む鉛直面内に拘束さ れた二次元問題である」としてこの運動の解析を行ってお り，またその解法で充分な結果が得られている

しかし一部のロケットにおいてはロケットとランチャー が特殊な形状をしており大きな鉛直面外方向の力が作用す るため, 三次元問題として解析を行う必要がある. 本論文 の目的は，そのような例外に対する三次元問題の解法を提 案することである．本論文でモデルとして扱うViper と 呼ばれる観測ロケットはその例外の一つである。Viper ロ ケット及びランチャーを第 1 図に示す。

Viper は第 1 図に示す 2 段式ロケットである。Viperの 発射には同図に示す螺旋状レールを持ったランチャーを用 いる．なお以降レール中心軸とは螺旋状レールの螺旋の中 心軸を指すものとする．螺旋状レールの断面を第 2 図に示 す。な抢同図には，ロケットからレールに及ぼされる力が 太矢印で示されている。(2.3.5 節参照) レール内面には 上段部の翼をはめ込む切欠があり，発射時には翼はレール に沿って運動するようになっている。下段部モーター最後 部は他の部分より径が大きく，その部分もレール内面と接

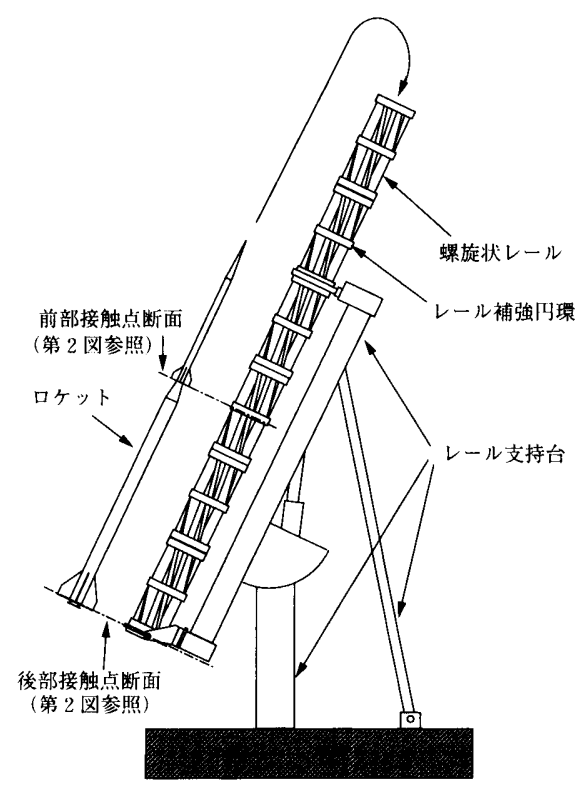

第1図 Viper ロケット及びランチャー
触する。このとき下段部の翼はそれぞれレールの間に位置 し，レールと干渉しないようになっている。またレール最 後部には落下防止用金具があり，発射前のロケット後端を 支える．発射時には上段の翼が螺旋状のレールに沿って運 動するため，口ケットにスピンが与えられる，逆にこの反 力がレールに作用し，ランチャーは鉛直面外にも変形す る。またロケット自身もスピンするため機体側でもピッ チ，ヨーのカップリングが生ずる．このため三次元問題と して運動の解析を行う必要がある。

実際のViper の打ち上げにおいてレーダー捕捉に失敗 した例があり，そのときロケットとランチャーの弾性変形 により予期した以上の軌道分散が生じた可能性が考えられ た。そこで本論文ではロケットとランチャーの弾性変形を 含む発射時の運動の解析を三次元で行い, 弾性変形に起因 する軌道分散量の推定を行う。

\section{2. 数值シミュレーション}

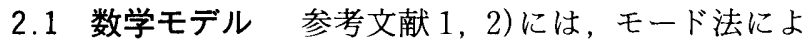
り低次元化したモデルを用いて，1節で述べた二次元問題 としての発射時の運動を精度良く予測できることが示され ている. 本論文でも同様にモード法を用いて低次元化を行 う. 固有振動モードの導出には, ロケットは 1 本, ランチ ヤーは 5 本の梁で構成された第 3 図に示す数学モデルを用 いる.

ロケットがランチャーから離脱するまでは，ロケット及 びランチャーは互いに接触しており，互いに力を及ほしあ っている．本論文ではこの接触部分は仮想的な質量を持た ないバネで近似し, 力はそのバネを介して伝達されるとす る。またこのバネは機体に固定されており，バネを介した 力及びモーメントはレール中心軸及び機体中心軸上に作用 すると仮定する。

2.2 座標系定義 解析には, 地上に固定された静止座 標系 $(X, Y, Z)$ と，ロケットに固定された動座標系 $(x, y$, z)を用いる。両者はともに直交座標系とする．第 3 図に 数学モデル及び座標系を示す。なお本論文ではロケットの

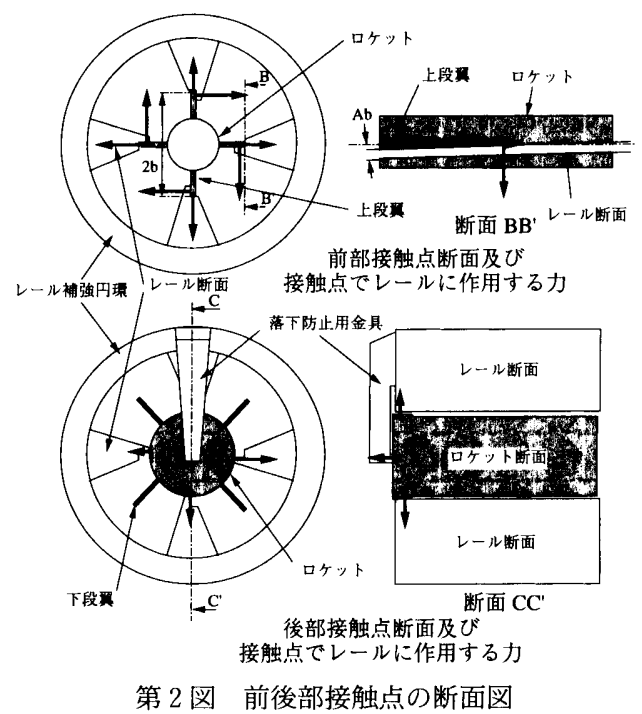

第 2 図 前後部接触点の断面図 
飛距離が短いため, 地球が球であることの影響や地球の公 転/自転の影響は無視して解析を行う。

座標系 $(X, Y, Z)$ の原点は, ランチャーが弾性変形し ていない状態のレール中心軸上の, ある代表点にとる，原 点からロケットを発射する方向を此として $X$ 軸をとる. $Z$ 軸は鉛直面内に重力の $Z$ 方向成分が負となるようにと る、 $Y$ 軸は座標系が右手系となるようにとる。

座標系 $(x, y, z)$ の原点はロケットの重心にとる.機体 中心軸に沿って前方が正になるように $x$ 軸をとる。 $z$ 軸 は，口ケット発射前の釣合状態で $z$ 軸が鉛直面内に含ま れ, かつ, 重力の $z$ 方向成分が負となるようにとる。 $y$ 軸 は座標系が右手系となるようにとる，このとき，ロケット は軸対称なので, $x, y, z$ 軸は慣性主軸と一致する。また， 発射前のロケットとランチャーの釣合状態におけるロケッ 卜の重心位置を $\left(X_{C G 0}, Y_{C G 0}, Z_{C G 0}\right)$ とする。

両座標系の相対的な関係は, 原点の相対位置とオイラー 角を用いて表す。才イラ一角 $(\Phi, \Theta, \Psi)$ は， $Z$ 軸周りの 角度 $\Psi, Y$ 軸周りの角度 $\Theta ， X$ 軸周りの角度 $\Phi$ の順に とる.このとき, $\Theta=\pi / 2$ が特異点となるが, 実際の発射 時にはピッチ，ヨ一方向の角度変化 $\Theta ， \Psi$ は小さいので, 取り扱いの障害とはならない.

2.3 運動方程式口ケットの剛体自由度は固有振動数 が0の振動モードとして扱うことも可能であるが, 現実の 物理量としての理解を容易にするために, 剛体自由度は弾 性振動モードとは別に運動方程式を立てる。剛体自由度で 決まる重心位置及び姿勢に, 弾性振動モードによる変形を 加えて, ロケットの弾性変形を含めた運動を表現する。

また，ロケット固定の座標系 $(x, y, z)$ が静止座標に対 して角速度 $\vec{\omega}=(p, q, r)$ で回転している場合， $(x, y, z)$ 座 標系での見かけの時間微分を $\delta / \delta t \equiv(う)$ とすると, ある ベクトル量 $\vec{v}=\left(v_{x}, v_{y}, v_{z}\right)$ に対する時間微分が

$$
\frac{\mathrm{d} \vec{v}}{\mathrm{~d} t}=\frac{\delta \vec{v}}{\delta t}+\vec{\omega} \times \vec{v}
$$

となることを考慮して運動方程式を導く.

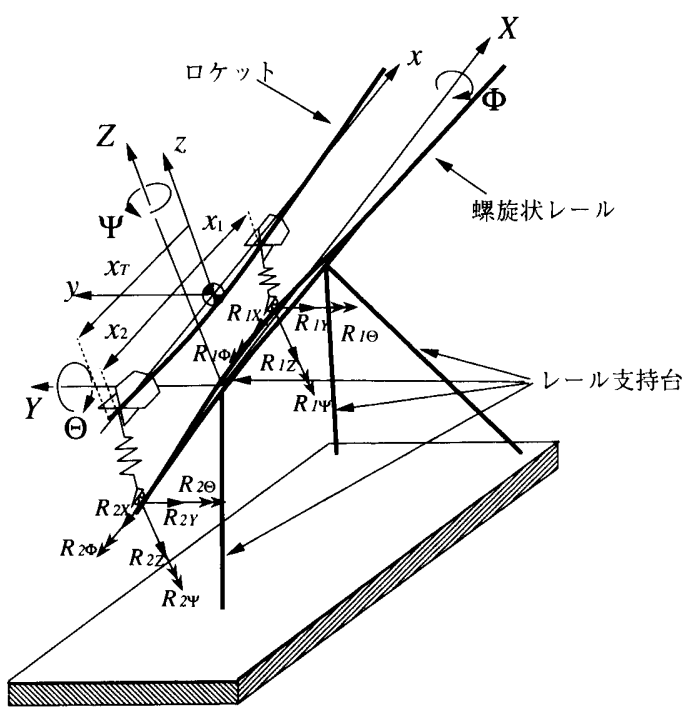

第 3 汹 数学モデル及び座標系
2.3.1 ロケット剛体自由度の運動方程式 ロケットに 作用する力は, 推力, 重力, ランチャーとの接触による反 力及び空気力と考える.ここでは推力は作用点における機 軸の接線方向に, 空気力は局所迎角に比例し $x$ 軸に対し て垂直に作用するとする。 また, 空気力の抗力成分は無視 できるとする， $x, y, z$ 軸は慣性主軸であるので $I_{i j}=0(i, j$ $=x, y, z ; i \neq j)$ を考慮し, $\Theta, \Psi \ll 1$ と, 弾性変形は微少 であることを用いて式を簡略化すると, 剛体自由度の運動 方程式は次の式となる。

$$
\begin{aligned}
& m\left(\dot{v}_{x}+q v_{z}-r v_{y}\right) \\
& =T-m g \sin \left(\Theta_{L I}-\Theta\right)+r_{1 x}+r_{2 x} \\
& m\left(\dot{v}_{y}+r v_{x}-p v_{z}\right) \\
& =\left[\sum_{i=1}^{N_{R}} \eta_{R i \psi}\left(x_{T}\right) \xi_{R i}\right] T-m g \cos \left(\Theta_{L I}-\Theta\right) \sin \Phi \\
& \quad+r_{1 y}+r_{2 y}+\frac{1}{2} \rho_{a} v^{2}\left[\left[C_{N \alpha}(x) S_{D} \alpha_{y}(x)\right]\right]_{R}
\end{aligned}
$$

$m\left(\dot{v}_{z}+p v_{y}-q v_{x}\right)$

$$
\begin{aligned}
= & -\left[\sum_{i=1}^{N_{R}} \eta_{R i \theta}\left(x_{T}\right) \xi_{R i}\right] T-m g \cos \left(\Theta_{L I}-\Theta\right) \cos \Phi \\
& +r_{1 z}+r_{2 z}+\frac{1}{2} \rho_{a} v^{2}\left[\left[C_{N \alpha}(x) S_{D} \alpha_{z}(x)\right]\right]_{R}
\end{aligned}
$$

$I_{x x} \dot{p}+\left(I_{z z}-I_{y y}\right) q r=r_{1 \phi}+r_{2 \phi}$

$I_{y y} \dot{q}+\left(I_{x x}-I_{z z}\right) r p$

$$
\begin{aligned}
= & r_{1 \theta}+r_{2 \theta}-x_{1} r_{1 z}-x_{2} r_{2 z}+x_{T}\left[\sum_{i=1}^{N_{K}} \eta_{R i \theta}\left(x_{T}\right) \xi_{R i}\right] T \\
& -\frac{1}{2} \rho_{a} v^{2}\left[\left[C_{N \alpha}(x) S_{D} x \alpha_{z}(x)\right]\right]_{R}+\left[\sum_{i=1}^{N_{R}} \eta_{R i z}\left(x_{T}\right) \xi_{R i}\right] T
\end{aligned}
$$

$$
\begin{aligned}
I_{z z} \dot{\gamma} & +\left(I_{y y}-I_{x x}\right) p q \\
= & r_{1 \psi}+r_{2 \psi}+x_{1} r_{1 y}+x_{2} r_{2 y}+x_{T}\left[\sum_{i=1}^{N_{R}} \eta_{R i \psi}\left(x_{T}\right) \xi_{R i}\right] T \\
& +\frac{1}{2} \rho_{a} v^{2}\left[\left[C_{N \alpha}(x) S_{D} x \alpha_{y}(x)\right]\right]_{R}-\left[\sum_{i=1}^{N_{K}} \eta_{R i y}\left(x_{T}\right) \xi_{R i}\right] T
\end{aligned}
$$

ここで $r_{i x}, r_{i y}, r_{i z}, r_{i \phi}, r_{i \theta}, r_{i \psi}(i=1,2)$ は, ランチャーと の接触による反力であり，次の式で表される.

$$
\begin{aligned}
& \left(r_{i x}, r_{i y}, r_{i z}\right)^{t}=-E\left(R_{i x}, R_{i y}, R_{i z}\right)^{t} \\
& \left(r_{i \phi}, r_{i \theta}, r_{i \psi}\right)^{t}=-E\left(R_{i \Phi}, R_{i \Theta}, R_{i \Psi}\right)^{t}
\end{aligned}
$$

ただし $E$ はオイラー角 $(\Phi, \Theta, \Psi)$ を用いて次の式で表さ れる $(X, Y, Z)$ 座標系から $(x, y, z)$ 座標系への変換行列 である

$$
E=\left(\begin{array}{ccc}
1 & \Psi & -\Theta \\
\Theta \sin \Phi-\Psi \cos \Phi & \cos \Phi & \sin \Phi \\
\Theta \cos \Phi+\Psi \sin \Phi & -\sin \Phi & \cos \Phi
\end{array}\right)
$$

また $\alpha_{y}(x), \alpha_{z}(x)$ はそれぞれ $x y, x z$ 平面内での局所迎角 であり，次のように表される。

$$
\begin{aligned}
\alpha_{y}(x)= & -\tan ^{-1}\left(\frac{v_{y}+x r}{v}+\sum_{j=1}^{N_{R}} \frac{\eta_{R j y}(x) \dot{\xi}_{R j}}{v}\right) \\
& +\sum_{j=1}^{N_{R}} \eta_{R j \psi}(x) \xi_{R j} \\
\alpha_{z}(x)= & -\tan ^{-1}\left(\frac{v_{z}-x q}{v}+\sum_{j=1}^{N_{R}} \frac{\eta_{R j z}(x) \dot{\xi}_{R j}}{v}\right) \\
& -\sum_{j=1}^{N_{R}} \eta_{R j \theta}(x) \xi_{R j}
\end{aligned}
$$


2.3.2 オイラ一角及びロケット重心位置の時間微分 オイラー角の時間微分及びロケット重心位置の時間微分は 次の式で表される。

$$
\begin{aligned}
\dot{\Phi}= & p+q \Theta \sin \Phi+r \Theta \cos \Phi \\
\dot{\Theta}= & q \cos \Phi-r \sin \Phi \\
\dot{\Psi}= & q \sin \Phi+r \cos \Phi \\
\dot{X}_{C G}= & v_{x}+v_{y}(\Theta \sin \Phi-\Psi \cos \Phi) \\
& +v_{z}(\Theta \cos \Phi+\Psi \sin \Phi) \\
\dot{Y}_{C G}= & v_{x} \Psi+v_{y}(\Theta \Psi \sin \Phi+\cos \Phi) \\
& +v_{z}(\Theta \Psi \cos \Phi-\sin \Phi) \\
\dot{Z}_{C G}= & -v_{x} \Theta+v_{y} \sin \Phi+v_{z} \cos \Phi
\end{aligned}
$$

2.3.3 ロケットの振動モードの運動方程式 ロケット の固有角振動数 $\omega_{R i}$, モード形状 $\eta_{R i x}, \eta_{R i y}$ 等は, 口ケッ トが静止した状態で求めたものである。この固有振動モー ドを用いて，回転するロケットの弾性振動を表現する方程 式を求める，そのためにまず，口ケットを表す梁の弾性変 形 $\vec{w}$ の運動方程式を, 回転する $(x, y, z)$ 座標系で記述し た式を求める。座標系 $(x, y, z)$ が角速度 $\vec{\omega}=(p, q, r)$ で 回転しているとき, 梁の弾性変形による運動エネルギ $M$ と歪みエネルギ $\Pi$ は次の式で表される。

$$
\begin{aligned}
& M=\left[\left[\frac{1}{2} \mu_{R}(\dot{\dot{w}}+\vec{w} \times \vec{w}) \cdot(\dot{\vec{w}}+\vec{\omega} \times \vec{w})\right]\right]_{R} \\
& \Pi=\left[\left[\frac{1}{2} J\left(\frac{\partial^{2} \vec{w}}{\partial x^{2}}\right) \cdot\left(\frac{\partial^{2} \vec{w}}{\partial x^{2}}\right)\right]\right]_{R}
\end{aligned}
$$

ただしJは梁の曲げ剛性であり，また，梁は充分に細く 梁の断面の回転慣性の項は無視できるとした． $L=M-\Pi$ で定義されるラグランジュ関数 $L$ から変分原理を用いて $\dot{w}$ の運動方程式を導くと，次の式が得られる。

$$
\begin{aligned}
& \mu_{R}\{\ddot{\ddot{w}}+\dot{\vec{\omega}} \times \vec{w}+2 \vec{\omega} \times \dot{\vec{w}}+\vec{\omega} \times(\vec{\omega} \times \vec{w})\}+\frac{\partial^{2}}{\partial x^{2}}\left(J \frac{\partial^{2} \vec{w}}{\partial x^{2}}\right) \\
& \quad=\vec{f}
\end{aligned}
$$

ただし $\vec{f}$ は，梁に作用する外力を $(x, y, z)$ 座標系で記述 した力である。

ここで弾性変形 $゙$ を固有振動モードを用いて次のよう に近似する。

$$
\vec{w}=\sum_{i=1}^{N_{R}} \vec{\eta}_{R i} \xi_{R i}
$$

ただし， $\vec{\eta}_{R i}$ は次の式で表されるべクトルである。

$$
\vec{\eta}_{R i}=\left(\eta_{R i x}, \eta_{R i y}, \eta_{R i z}\right)
$$

式(22)を式(21)に代入して整理すると,

$$
\begin{gathered}
\sum_{i=1}^{N_{k}}\left\{\frac{\mathrm{d}^{2}}{\mathrm{~d} x^{2}}\left(J \frac{\mathrm{d}^{2} \vec{\eta}_{R i}}{\mathrm{~d} x^{2}}\right) \xi_{R i}+\vec{\eta}_{R i} \mu_{R} \ddot{\xi}_{R i}+\mu_{R} \dot{\omega} \times \vec{\eta}_{R i} \xi_{R i}\right. \\
\left.\quad+2 \mu_{R} \vec{\omega} \times \vec{\eta}_{R i} \dot{\xi}_{R i}+\mu_{R} \vec{\omega} \times\left(\vec{\omega} \times \vec{\eta}_{R i}\right) \xi_{R i}\right\}=\vec{f}
\end{gathered}
$$

となる．両辺と $\vec{\eta}_{R j}$ の内積をとって積分し， $\vec{\eta}_{R i}$ が

$\left[\left[\mu_{R} \vec{\eta}_{R j} \cdot \vec{\eta}_{R i}\right]\right]_{R}=m \delta_{i j}$

$\left[\left[\vec{\eta}_{R j} \cdot \frac{\mathrm{d}^{2}}{\mathrm{~d} x^{2}}\left(J \frac{\mathrm{d}^{2} \ddot{\eta}_{R i}}{\mathrm{~d} x^{2}}\right)\right]\right]_{R}=m \omega_{R j}^{2} \delta_{i j}$

のように直交化していることを考慮すると，

$m\left(\omega_{R j}^{2} \xi_{R j}+\ddot{\xi}_{R j}\right)-m \vec{\omega} \cdot \vec{\omega} \xi_{R j}$

$$
=\sum_{i=1}^{N_{R}}\left(m \vec{C}_{i j} \cdot \dot{\hat{\omega}} \xi_{R i}+2 m \vec{C}_{i j} \cdot \dot{\omega} \dot{\xi}_{R i}\right)+\left[\left[\dot{\eta}_{R j} \cdot \vec{f}\right]\right]_{R}
$$

を得る。ここで $\delta_{i j}$ はクロネッカーの $\delta て ゙ あ り ， \vec{C}_{i j}$ は

$$
m \vec{C}_{i j}=\left[\left[\mu_{R}\left(\vec{\eta}_{R i} \times \vec{\eta}_{R j}\right)\right]\right]_{R}
$$

と定義されるべクトルである。モード形状 $\vec{\eta}_{R i}$ は自由境界 の条件で求めたモードを用いるので, 各振動モードは剛体 変位を表す一様変位のモードと質量に関して直交してい る。そのため, 質量に比例する体積力である重力は各振動

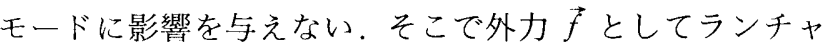
一との接触による反力, 推力, 及び空気力を考慮し,さら にモード減衰 $\zeta_{R i}$ を加えて式(27)を整理すると，ロケット の固有振動の運動方程式は次の式で表される。

$$
\begin{aligned}
& m\left(\ddot{\xi}_{R i}+2 \zeta_{R i} \omega_{R i} \dot{\xi}_{R i}+\omega_{R i}^{2} \xi_{R i}\right) \\
&=\sum_{j=1}^{N_{R}}\left(m \vec{C}_{j i} \cdot \dot{\vec{\omega}} \xi_{R j}+2 m \vec{C}_{j i} \cdot \vec{\omega} \dot{\xi}_{R j}\right) \\
& \quad+m \dot{\omega} \cdot \dot{\omega} \xi_{R i}+\boldsymbol{r}_{1} \cdot \eta_{R i}\left(x_{1}\right)+\boldsymbol{r}_{2} \cdot \eta_{R i}\left(x_{2}\right) \\
& \quad+T\left[\sum_{j=1}^{N_{R}} \eta_{R j \psi}\left(x_{T}\right) \xi_{R j}\right] \eta_{R i y}\left(x_{T}\right) \\
& \quad-T\left[\sum_{j=1}^{N_{R}} \eta_{R j \theta}\left(\ddot{x}_{T}\right) \xi_{R j}\right] \eta_{R i z}\left(x_{T}\right) \\
& \quad+\frac{1}{2} \rho_{a} v^{2}\left[\left[C_{N \alpha}(x) S_{D} \eta_{R i z}(x) \alpha_{z}(x)\right]\right]_{R} \\
&+\frac{1}{2} \rho_{a} v^{2}\left[\left[C_{N \alpha}(x) S_{D} \eta_{R i y}(x) \alpha_{y}(x)\right]\right]_{R}
\end{aligned}
$$

ここで $\boldsymbol{r}_{i}, \boldsymbol{\eta}_{R i}(i=1,2)$ は, 次の式で定義される 6 次元の ベクトルである。

$$
\begin{aligned}
& \boldsymbol{r}_{i}=\left(r_{i x}, r_{i y}, r_{i z}, r_{i \phi}, r_{i \theta}, r_{i \psi}\right) \\
& \eta_{R i}=\left(\eta_{R i x}, \eta_{R i y}, \eta_{R i z}, \eta_{R i \phi}, \eta_{R i \theta}, \eta_{R i \psi}\right)
\end{aligned}
$$

2.3.4 ランチャーの振動モードの運動方程式 ランチ ヤーに作用する力として重力及びロケットとの接触による 反力を考える。このとき, ランチャーの弾性振動モードの 運動方程式は次の式で表される。

$$
\begin{aligned}
m_{L} & \left(\ddot{\xi}_{L i}+2 \zeta_{L i} \omega_{L i} \dot{\xi}_{L i}+\omega_{L i}^{2} \xi_{L i}\right) \\
= & \boldsymbol{R}_{\mathbf{1}} \cdot \boldsymbol{\eta}_{L i}\left(x_{1}+X_{C G}+X_{C G 0}, 0,0\right) \\
& +\boldsymbol{R}_{2} \cdot \boldsymbol{\eta}_{L i}\left(x_{2}+X_{C G}+X_{C G 0}, 0,0\right) \\
& -\left[\left[\mu_{L} \boldsymbol{g} \cdot \boldsymbol{\eta}_{L i}(X, Y, Z)\right]\right]_{L}
\end{aligned}
$$

なお， ロケットの場合は一本の梁であるので各関数の引数 には $x$ のみを用いているが, ランチャーは三次元の構造 物であるので，(32)式では関数の引数に $X, Y, Z$ のつ を用いている。ここで，(32)式右辺第 1,2 項の $\eta_{L i}$ の $Y$, $Z$ 引数が 0 であるのはレール中心軸上のモード形状であ ることを示し，また，第 3 項はランチャ一全体にわたる積 分であることを示している.ここで $\boldsymbol{R}_{i}, \boldsymbol{\eta}_{L i}, \boldsymbol{g}(i=1,2)$ は, 次の式で定義される 6 次元のベクトルである.

$$
\begin{aligned}
& \boldsymbol{R}_{i}=\left(R_{i X}, R_{i Y}, R_{i Z}, R_{i \Phi}, R_{i \Theta}, R_{i \Psi}\right) \\
& \boldsymbol{\eta}_{L i}=\left(\eta_{L i X}, \eta_{L i Y}, \eta_{L i z}, \eta_{L i \Phi}, \eta_{L i \Theta}, \eta_{L i \Psi}\right) \\
& \boldsymbol{g}=\left(g \sin \Theta_{L I}, 0, g \cos \Theta_{L I}, 0,0,0\right)
\end{aligned}
$$

2.3.5 ロケットとランチャーの接触による反カ ロケ ットとランチャーの接点は 1 節で述べたように前後 2 力所 ある. 反力 $\boldsymbol{R}_{i}$ の添字 $i=1$ のときは前部接点で, 添字 $i=$ 2 のときは後部接点で発生する力であることを示す.

第 2 図上半に $\boldsymbol{R}_{1}$ が生じる前部接点のロケットとレール の断面，及びその接点でレールに作用する力を示す．特殊 なレール断面形状のため, 翼とレールは, 翼面及び翼端面 
で接触している。第 2 図左上の $Y Z$ 面に含まれる力の合 力は, レール中心軸に垂直な $Y, Z$ 方向の力 $R_{1 Y}, R_{1 Z}$ 及 びレール中心軸周りのモーメント $R_{1 \Phi}$ で表すことができ る.しかし実際の螺旋状レールはロケットの翼面に対して 斜めに接触している (第 2 図右上参照). 発生する力はレ ールの面に垂直であるので, その分力としてレール中心軸 に垂直な成分の他に平行な（ $X$ 方向）成分が得られる. ここで計算の簡略化のため， $X$ 方向成分は 4 つ接点で 等しく， $Y, Z$ 軸周りのモーメントを発生しないと仮定す る。また, 翼端面の接触による力の作用線はレール中心軸 を通りレール中心軸周りのモーメントを発生しないと仮定 する.このとき, 翼面の接触により発生する力の $X$ 方向 成分は $R_{1 \Phi} / b \cdot \tan A b$ で与えられる。2.1 節で述べたよう に，これらの力はバネを用いてモデル化する． $R_{1 Y}, R_{1 Z}$ を 与えるバネ定数を $K_{1}, R_{1 \Phi}$ 与えるバネ定数を $K_{1}^{*}$ 与す る.

第 2 図下半に $\boldsymbol{R}_{2}$ が生じる後部接点のロケットとレール の断面，及びその接点でレールに作用する力を示す．これ らの力の作用線も $\boldsymbol{R}_{1}$ の場合と同様にレール中心軸を通る と仮定すると, 合力の成分として $R_{2 X}, R_{2 Y}, R_{2 Z}$ が得られ る. $R_{2 Y}, R_{2 Z}$ を与えるバネ定数を $K_{2}, R_{2 X}$ を与えるバネ定 数を $K_{2}^{*}$ とする.

以上の力以外に, 各接触点で発生する $X$ 方向の摩擦力 (係数 $\left.\mu_{i}\right)$ を考虑する. それ以外の力 $\boldsymbol{R}_{i}(i=1,2) 0$ 成分 $R_{2 \Phi}, R_{i \oplus,}, R_{i \Psi}(i=1,2)$ は 0 とする. 以上の記述を整理す ると, $R_{i Y}, R_{i Z}, R_{1 X}(i=1,2)$ は下記の式(36)から(38)の 式で表される。

$$
\begin{aligned}
& R_{i Y}=K_{i} D_{i Y} \\
& R_{i Z}=K_{i} D_{i Z} \\
& R_{1 X}=\frac{R_{1 \Phi}}{b} \tan A b+\mu_{1}\left(\left|R_{1 Y}\right|+\left|R_{1 Z}\right|+\left|\frac{R_{1 \Phi}}{b}\right|\right)
\end{aligned}
$$

また，第 2 図に示したレール形状のため，実際にはレール に対して $\Phi$ の正方向のトルクしか作用しないことを考慮

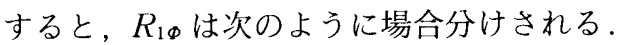

$$
R_{1 \Phi}= \begin{cases}K_{1}^{*} D_{1 \Phi} & D_{1 \Phi} \geq 0 \\ 0 & D_{1 \Phi}<0\end{cases}
$$

同様に，第 2 図に示す形状のため，落下防止用金具による 力は $X$ の負方向にしか作用しないことを考慮すると， $R_{2 X}$ は次のように場合分けされる。

$$
R_{2 X}= \begin{cases}K_{2}^{*} D_{2 X}+\mu_{2}\left(\left|R_{2 Y}\right|+\left|R_{2 Z}\right|\right) & D_{2 X} \leq 0 \\ \mu_{2}\left(\left|R_{2 Y}\right|+\left|R_{2 Z}\right|\right) & D_{2 X}>0\end{cases}
$$

ここで $D_{i Y}, D_{i Z}, D_{1 \Phi}, D_{2 X}$ はロケット, ランチャー間の相 対変位量であり，次の式で表される。

$$
\begin{aligned}
& D_{i Y}=Y_{C G}-Y_{C G 0}+\Psi_{x_{i}}+d_{i Y}-D_{i Y}^{*} \\
& D_{i Z}=Z_{C G}-Z_{C G 0}-\Theta x_{i}+d_{i Z}-D_{i Z}^{*} \\
& D_{1 \Phi}=\Phi-A\left(X_{C G}-X_{C G 0}\right)-D_{1 \Phi}^{*} \\
& D_{2 X}=X_{C G}-X_{C G 0}+d_{2 X}-D_{2 X}^{*}
\end{aligned}
$$

ここで $\left(d_{i X}, d_{i Y}, d_{i Z}\right)(i=1,2)$ はロケットの弾性変形によ る変位量であり, 次の式で表される。

$$
\left(d_{i X}, d_{i Y}, d_{i z}\right)^{t}=E^{-1}\left(d_{i x}, d_{i y}, d_{i Z}\right)^{t}
$$

$$
d_{i j}=\sum_{k=1}^{N_{R}} \eta_{R k j}\left(x_{i}\right) \xi_{R k} \quad(j=x, y, z)
$$

また $D_{i j}^{*}(i=1,2, j=X, Y, Z, \Phi)$ はランチャーの弾性変 形による変位量であり, 次の式で表される。

$$
D_{i j}^{*}=\sum_{k=1}^{N_{L}} \eta_{L k j}\left(X_{C G 0}+X_{C G}+x_{i}, 0,0\right) \xi_{L k}
$$

ただし以上の力はロケットがランチャーから離脱するま で, 即ち $X_{C G}<X_{R C G i}(i=1,2)$ のときに限り発生するもの である. $X_{C G} \geq X_{R C G i}(i=1,2)$ のをは $\boldsymbol{R}_{i}=0(i=1,2) て ゙$ ある。なお Viperでは, 前後部の接点はほほ同時にラン チャーから離脱するように設計されており， $X_{R C G 1}=2.50$ $(\mathrm{m}), X_{R C G 2}=2.46(\mathrm{~m})$ である.

\section{3. 計測データとの比較}

3.1 実飛翔時のデータとの比較 2.3 節に示した式 （2）から (47) を数值積分することにより，シミュレーショ ンを行う. 数值シミュレーションに用いるロケットの固有 振動モードは, ロケットの図面から密度と剛性を求めて計 算した。ロケットの基本寸法と 3 次までの固有振動数及び モード形状を第 4 図に示す。ロケットは軸対称であるの で,同一周波数に $x y$ 面内と $x z$ 面内で変形する $2 つ 0 モ$ ードが存在する。またランチャーの固有振動モードは, 図 面に基づく值に振動試験を行って修正を加えたモードを用 いた．ランチャーの螺旋状レール部の基本寸法と 3 次まで の固有振動数及びモード形状（レール部のみ）を第 5 図に 示す.ランチャー0場合は, 1 次モードと 3 次モードはレ ールが $X Y$ 面内で変形するモード, 2 次モードはレール が $X Z$ 面内で変形するモードとなっている.

次に $K_{1}, K_{2}, K_{1}^{*}, K_{2}^{*}$ であるが，これらは接触部に仮想 的に導入されたバネのバネ定数であるので，厳密な值を決 定することは困難である。ここでは接触部に関連する構造 物のうち，最も剛性の低い構造物から決まるバネ定数が支 配的であるとしてバネ定数を推定した，Klについては， 上段翼が取り付けられているアルミ製円筒（半径 $22.5(\mathrm{~mm})$, 厚さ $0.5(\mathrm{~mm})$, 長さ $80(\mathrm{~mm})$, 両端固定 $)$ が母線に沿って一様な半径方向線荷重を受けた場合の力と 変位の関係から $K_{1}=2.0 \times 10^{6}(\mathrm{~N} / \mathrm{m})$ とした. 同様に $K_{2}$ についてはレールと接触している胴体最後部アルミ製円筒 (半径 $57.5(\mathrm{~mm})$, 厚さ $1.0(\mathrm{~mm})$, 長さ $25(\mathrm{~mm})$, 両端 固定）が母線に沿って一様な半径方向線荷重を受けた場合 の力と変位の関係から $K_{2}=5.0 \times 10^{6}(\mathrm{~N} / \mathrm{m})$ とした．また $K_{1}^{*}$ については，4枚のアルミ製上段翼（厚さ $2(\mathrm{~mm}$ ), 平 均翼弦 $60(\mathrm{~mm})$, 翼部分の幅 $42(\mathrm{~mm}))$ の曲げ岡性とロ ケットの中心軸から翼端までの距離 $65(\mathrm{~mm})$ から $K_{1}^{*}=3.5$ $\times 10^{3}(\mathrm{Nm} / \mathrm{rad}), K_{2}^{*}$ については，鋼製金具の寸法（厚さ $15(\mathrm{~mm})$, 幅 $15(\mathrm{~mm})$, 長さ $200(\mathrm{~mm}))$ から $K_{2}^{*}=1.0 \times$ $10^{6}(\mathrm{~N} / \mathrm{m})$ とした。また,このシミュレーションでは 60 ( $\mathrm{Hz})$ までの振動モード（ロケット側 6 モード, ランチャ 一側 9 モード）を用いた。

シミュレーションの精度を検証するため, Viper 2 号機 の打ち上げ時にランチャ一上で $Y, Z$ 方向加速度及び 


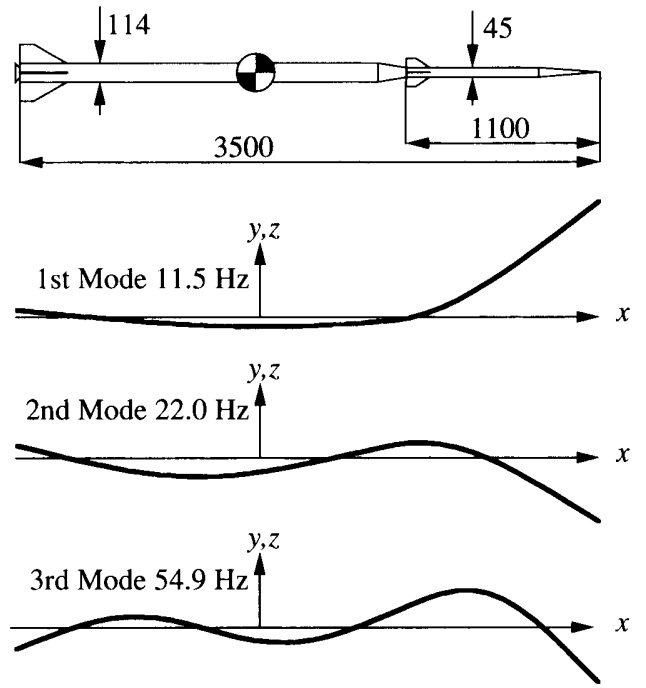

第 4 図 ロケットの固有振動モード
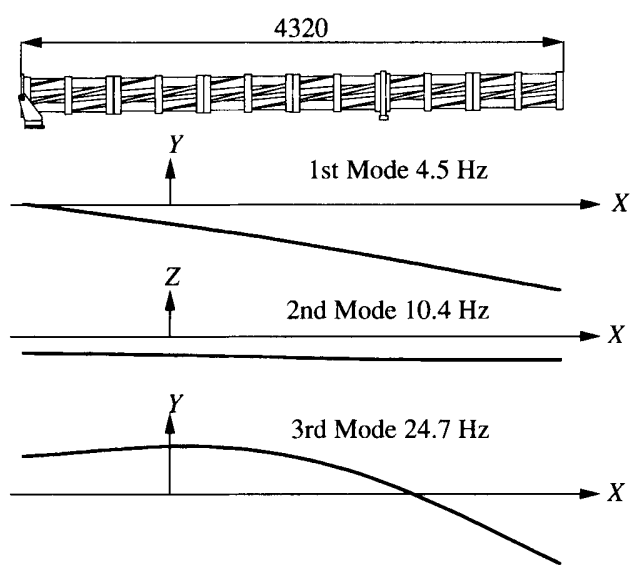

第 5 図 ランチャーの固有振動モード

$Y, Z$ 方向変位を実測した。加速度は抵抗線型加速度計, $Y$ 方向変位は高速度ビデオカメラ, $Z$ 方向変位は非接触 光学変位計を用いて計測した。

第 6〜9 図に計算值と実測值の比較を示す。なお実測デ 一タからは, カットオフ周波数 $60(\mathrm{~Hz})$ のバタワースフィ ルタを用いて, シミュレーションに含まれない高周波成分 を除去してある. 図中, $t=0(\mathrm{~s})$ がロケット点火時であ る. $t=0.1(\mathrm{~s})$ 付近で加速度の計算值が不連続に変化して いる部分があるが, これはロケットがランチャーから離脱 する瞬間である。この瞬間に実測值は連続であるのに計算 值が不連続となる理由は，本論文の計算ではモード法を用 いて高次モードを省略しているため, 計算では加速度が不 連続となるということと, 実測值に不連続性が含まれてい る場合にも，フィル夕処理のために不連続性が見え難くな るということであると考えられる。また，第 7 図の $Z$ 方 向変位では, 計測系の特性のため $t=0.17(\mathrm{~s})$ 付近で実測 データがとぎれている. 同様に第 6 図の $Y$ 方向変位では, 計測系の特性のため $30(\mathrm{~Hz})$ 以上の振動は実測デー夕に含 まれていない.

3.2 計算精度の考察 一般に軌道分散を決定するパラ

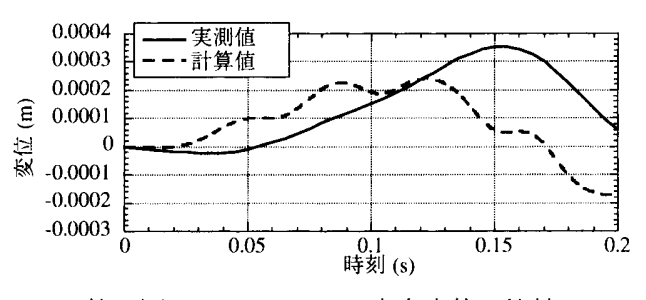

第 6 図 ランチャー $Y$ 方向溶位の比較

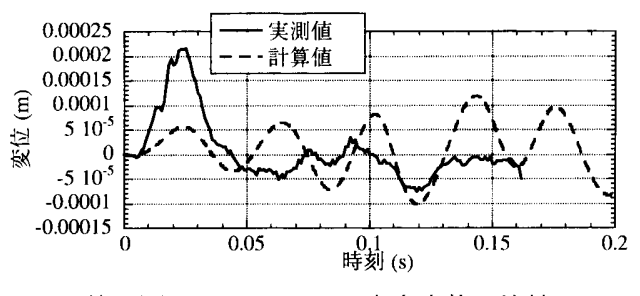

第 7 図 ランチャー $Z$ 方向変位の比較

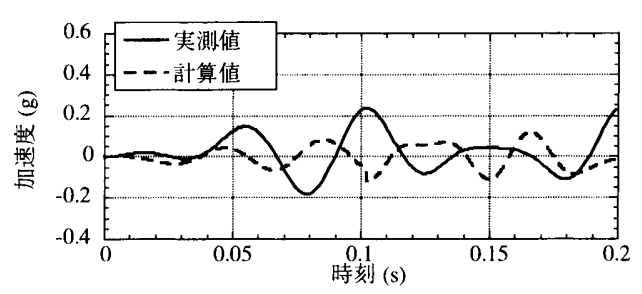

第 8 図 ランチャー $Y$ 方向加速度の比較

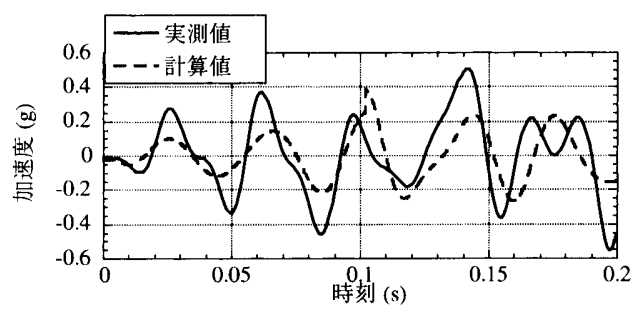

第 9 汹 ランチャー $Z$ 方向加速度の比較

メータは, ランチャーの振動, 風の影響, 機体のミスアラ イメント等，多岐にわたる。しかし本論文の目的はロケッ ト及びランチャーの弾性が軌道分散に及ぼす影響の評価で ある. 弾性の影響はロケット及びランチャーの変形及び振 動として現れる. 本解析によるランチャーの振動の計算結 果と実測值との比較は第 6〜9図に示した. 同図を見ると, 振動の振幅に関しては実測值に近い值が得られているが, 位相に関しては計算結果と実測値との差が大きい.

しかし，振動の位相は弾性のパラメータの影響を大きく 受ける. 実際に弾性のパラメータを変化させ試算を行う と, バネ定数 $K_{1}, K_{2}$, 特に $K_{1}$ の変化が振動位相に大き な影響を与えることが判明した。また同時に， $K_{1} ， K_{2}$ の 変化による振動振幅の変化は小さいことも判明した。

これは， $K_{1}, K_{2}$ の值を変化させ計算を行うことにより， ロケット及びランチャーの振動の振幅を保ったまま, 位相 を変化させて軌道分散を計算することが可能であることを 示す。その計算から得られた軌道分散の最大值の評価を行 えば，それは実際の打ち上げにおいて安全側の評価であ 
る。そこでこのシミュレーションを用いて軌道分散の最大 值を求める。

\section{4. 軌道分散の推定}

4.1 軌道分散の表現 軌道分散の評価は, 剛体ランチ ヤーを用いて剛体ロケットを打ち上げた場合の理想的な軌 跡との比較により行う。すなわち, 弾性を考慮して求めた 軌跡と剛体ランチャーで剛体ロケットを打ち上げた場合の 軌跡とが一致するランチャー角度を求め, 弾性を考慮した 場合としない場合とのランチャー角度の差を軌道分散量を 表す指標とする．以後方位角方向の軌道分散量は $\Delta \psi$, 上 下角方向の軌道分散量は $\Delta \theta$ と表す. 3.1 節の計算例の場 合, この指標の值は, $\Delta \psi=1.1(\mathrm{deg}), \Delta \theta=0.077(\mathrm{deg})$ である。

4.2 軌道分散の推定及び評価 3.1 節で行った $K_{1}$, $K_{2}$ の值の推定は非常に概算的であり, 推定精度はオーダ 一が一致する程度のものと考元られる。そこで $K_{1}$ 及び $K_{2}$ の值を $1 / \sqrt{10}$ から $\sqrt{10}$ 倍の間で 1 桁変化させて計算を行 った。第 10 図及び第 11 図に方位角方向及び迎角方向の軌 道分散の計算結果を示す。

第 10 図及び第 11 図を見ると， 3.2 節で触れたように， バネ定数 $K_{1}$ の変化が軌道分散に大きな影響を与えること がわかる。これは, Viperでは前後の接触部がほほ同時に ランチャーから離脱するように設計されているが，この場 合, 前部の接触点が打ち上げ中に通過する範囲のランチャ ーレールのモード変形の方が, 後部の接触点が通過する範 囲のランチャーレールのモード変形に比べて大きいため, 前部の接触点での振動の方が後部の接触点での振動よりも ランチャ一振動に与える影響が大きく, 結果として軌道分 散に与える影響も大きくなるためと考えられる.

第 10 図及び第 11 図の範囲では，方位角方向の軌道分散 の絶対値の最大值は $\Delta \psi=1.46(\mathrm{deg})$, また上下角方向の 軌道分散の絶対值の最大值は $\Delta \theta=0.19(\mathrm{deg})$ である. Viperの風補正計算データからこれらの值を風速に換算す ると，それぞれ約 $1.5(\mathrm{~m} / \mathrm{s})$ 及び $0.6(\mathrm{~m} / \mathrm{s})$ 程度の風によ って生じる值である. 実際の打ち上げは風速 $5 \sim 6(\mathrm{~m})$ 程 度の場合にも行われ，またレーダーの捜索も上下 \pm 2 度, 左右 \pm 4 度の範囲にわたり行われるため, この值は実用上 は問題のない值であると言える。

\section{5. 結論}

螺旋状のランチャーレールから発射されるロケットとそ のランチャーの運動について， ロケット及びランチャーの 弾性を考慮した三次元の運動方程式を定式化し，数値計算 結果と実際の打ち上げ時に計測されたデータの比較により 数值計算の精度の検討を行った。その結果, 本解析法を用 いてランチャーの振動の振幅を推定することが可能であ り，また特定のパラメー夕を変化させることにより軌道分

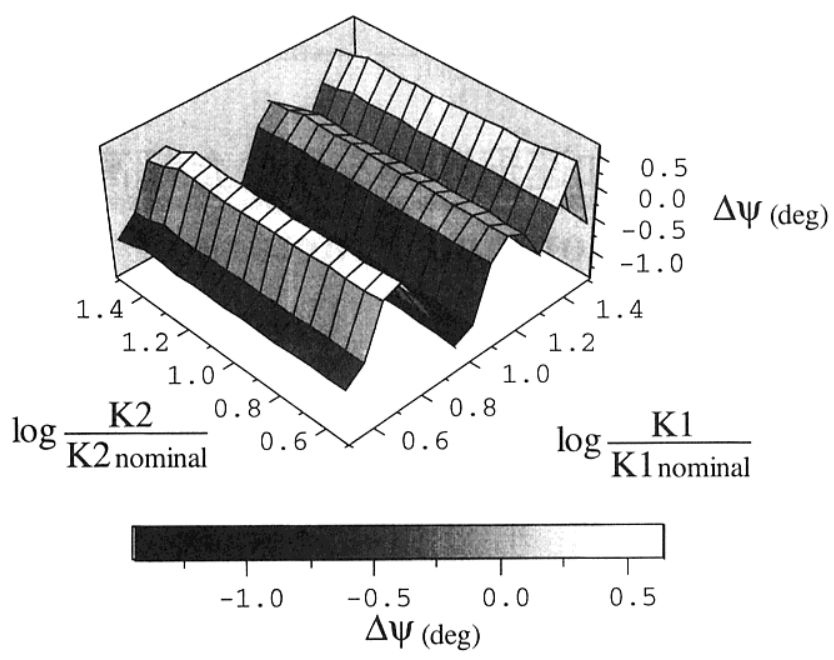

第 10 図方位角方向の軌道分散

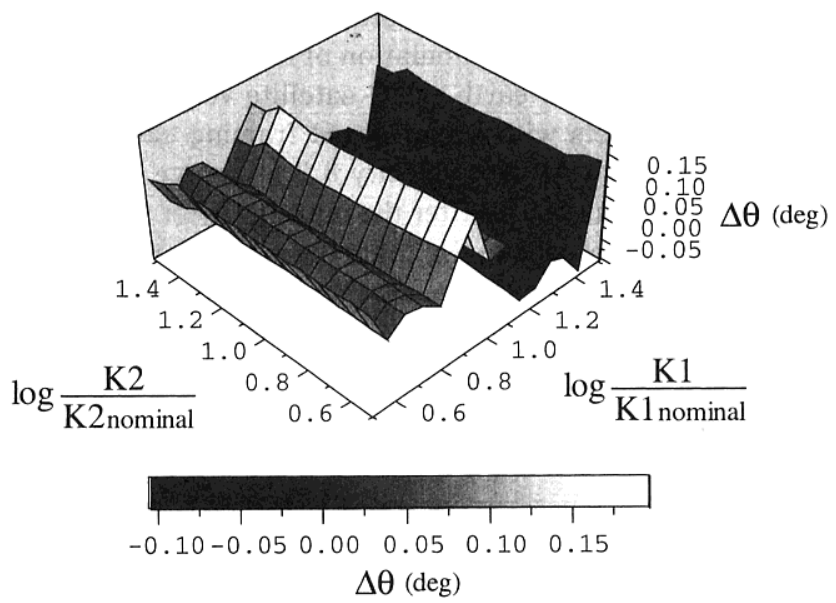

第 11 図上下角方向の軌道分散

散の最大值を求めることが可能であることが判明した。そ こで本解析法を用いて Viper ロケットの軌道分散の最大 值の推定を行い，ロケット及びランチャーの弾性による軌 道分散が実用上問題ない範囲の值であることを確認した。

本研究を進めるにあたり随時適切な助言を頂いた宇宙科 学研究所の小野田教授，また実際の飛翔デー夕の計測に協 力して頂いた同じく宇宙研の市田助手，橋元技官，富沢技 官，下瀬技官に紙面の最後を借りて感謝の意を表します。

\section{参 考 文 献}

1) Kishi, K., Onoda, J., Minesugi, K. and Nakamura, M. Dynamic Loads on Mu-Series Satellite Launch Vehicles at Lift Off, AIAA Paper 94-1708, 1994.

2) Onoda, J.: The Dynamic Bending Load on a Satellite Laun cher Due to Inclined Lift-off, Trans. Jpn. Soc. Aeronaut. Space Sci., 26 (1983), pp. 37-52. 